\title{
PERBEDAAN KEMATANGAN EMOSI REMAJA DITINJAU DARI STRUKTUR KELUARGA
}

\author{
Farokhatin Nashukah dan Ira Darmawanti \\ Program Studi Psikologi Universitas Negeri Surabaya \\ e-mail:f_vee17@yahoo.com,ira.darmawanti@gmail.com
}

\begin{abstract}
A family has a great influence on children's emotional patterns because the family is the first social group for children to learn and express themselves as human beings in a social interaction with their groups. The background of this study is the problem of adolescent emotional maturity attainment. Subjects in this study were devided into two groups which overall are 121 adolescents aged between 16 and 20 years old. This study uses simple random sampling technique with predetermined characteristics and scale of emotional maturity as an instrument. Test the assumptions used in this study are normality test using one sample Kolmogorov-Smirnov test technique and homogeneity test using homogenity of variance test technique. The normality test shows the value of adolescents of complete families is 0,789 and the value of adolescents of single parent families is 0,982. Significance value $>0.05$, then the variable of emotional maturity is declared normally. Homogenity test shows the value is 0,499. Significance value $>0,05$, then the variable of emotional maturity is declared homogeneous. Results of this study shown that adolescent emotional maturity of single parent families has a mean of 148,71 emotional maturity that is higher than a mean of the emotional maturity of a complete family of 143,77. Based on analysis data using t-test known that the significance value is $0,013(p>0.05)$, the result shows that the study hypothesis is accepted. It is concluded that there is difference of emotional maturity among adolescents influenced by their different family structures.
\end{abstract}

Keywords: Emotional maturity, family structure, adolescent.

\begin{abstract}
Abstrak: Keluarga memiliki pengaruh besar terhadap pola emosi anak karena keluarga merupakan kelompok sosial pertama untuk anak belajar dan menyatakan diri sebagai manusia sosial. Tujuan dalam penelitian ini adalah untuk mengetahui perbedaan kematangan emosi remaja ditinjau dari struktur keluarga, yaitu keluarga lengkap dan keluarga dengan orang tua tunggal (single parent). Peneliti menggunakan teknik simple random sampling dengan karakteristik yang telah ditentukan. Subjek pada penelitian ini adalah dua kelompok yang secara keseluruhan berjumlah 121 sampel dengan rentang usia 16-20 tahun. Instrumen penelitian yang digunakan adalah skala kematangan emosi. Uji asumsi menggunakan uji normalitas menggunakan teknik one sample KolmogorovSmirnov test dan uji homogenitas menggunakan teknik test of homogenity of variance. Diketahui bahwa uji normalitas remaja dari keluarga lengkap sebesar 0,789 , dan pada remaja dari keluarga single parent sebesar 0,982 . Nilai signifikansi $>0,05$, maka variabel kematangan emosi dinyatakan berdistribusi normal. Diketahui bahwa uji homogenitas dengan nilai sebesar 0,499. Nilai signifikansi $>0,05$, maka variabel kematangan emosi dinyatakan homogen. Hasil penelitian ini menunjukkan bahwa kematangan emosi remaja dari keluarga single parent memiliki rata-rata skor kematangan emosi 148,71 yang lebih tinggi daripada rata-rata skor kematangan emosi keluarga lengkap yang sebesar 143,77. Berdasarkan analisis data yang dilakukan dengan menggunakan Ujit, diketahui bahwa nilai signifikansi sebesar $0,013(p>0,05)$ yang menunjukkan hipotesis penelitian diterima sehingga peneliti menyimpulkan bahwa ada perbedaan kematangan emosi remaja ditinjau dari struktur keluarga.
\end{abstract}

Kata kunci: Kematangan emosi, stuktur keluarga, remaja.

Masa remaja merupakan proses transisi dari masa anak-anak menuju masa dewasa yang membutuhkan banyak penyesuaian dan seringkali menimbulkan kecemasan. Masa remaja juga merupakan suatu masa dimana ketegangan emosi meninggi, terutama karena 
berada dibawah tekanan sosial dan menghadapi kondisi baru sehingga sebagian besar remaja mengalami ketidakstabilan emosi dari waktu ke waktu sebagai konsekuensi dari usaha penyesuaian diri pada pola perilaku baru dan harapan sosial yang baru (Hurlock, 1996; Monks dkk., 2004). Kondisi emosi yang terjadi pada remaja tidak terlepas dari bermacam-macam pengaruh, seperti lingkungan tempat tinggal, keluarga, sekolah, dan teman-teman sebaya, serta aktivitas-aktivitas yang dilakukannya dalam kehidupan sehari-hari.

Keluarga merupakan lembaga pendidikan primer yang berperan dalam pembentukan norma-norma sosial dimana individu pertama-tama belajar memperhatikan keinginan orang lain, belajar bekerjasama, dan belajar memegang peranannya sebagai anggota masyarakat yang diikat oleh norma tertentu (Gerungan, 2010). Karena itu, keluarga memiliki pengaruh yang besar terhadap perkembangan emosi anak karena keluarga merupakan kelompok sosial pertama di mana anak belajar menunjukkan perilaku, menyatakan pikiran, serta mengekspresikan keinginan dan emosinya dalam sebuah interaksi sosial. Karena itu pengalaman interaksi anak dalam keluarga akan menentukan pola tingkah laku anak dalam hubungannnya dengan orang lain di masyarakat. Anak mengenal lingkungan keluarga dan menyerap norma-norma dan nilai yang berlaku di dalamnya menjadi bagian dari kepribadiannya yang akan bertahan hingga dewasa (Ahmadi, 2007).

Menurut Mōnks dkk. (2004), manusia dalam hidupnya mengalami dua perkembangan yaitu perkembangan fisik dan perkembangan mental. Perkembangan fisik dapat diukur dengan melihat usia kronolologis seseorang. Perkembangan mental dapat dilihat berdasarkan kemampuan dan pencapaian. Tingkat kemampuan perkembangan tertentu dalam perkembangan mental disebut dengan kematangan (maturity). Salah satu pencapaian kematangan yang dicapai individu adalah kematangan emosi.

Seseorang dapat dikatakan memiliki kematangan emosi jika dapat menunjukkan emosinya dalam derajat yang tepat dengan pengendalian diri yang wajar, juga akan mengekspresikan emosinya dalam cara yang dapat diterima lingkungan sosialnya yang cenderung lebih mengutamakan intelektualitas daripada emosinya (Manoharan \& Doss, 2007). Istilah kematangan emosi sering kali membawa implikasi adanya kontrol emosi. Menurut Chaplin (2006), kematangan emosi adalah suatu keadaan atau kondisi mencapai tingkat kedewasaan dari perkembangan emosional, sehingga individu tidak lagi menampilkan pola emosional seperti pada anak-anak. Kematangan emosi remaja usia sekolah dapat dilihat dari kemampuannya mengatur waktu belajar, waktu menyelesaikan tugas, waktu menikmati liburan, mengatur hubungan dengan teman dan segala sesuatu yang berkaitan dengan mengelola dan mengendalikan emosi kearah positif.

Chamberlain (dalam Pastey \& Aminbhavi, 2006) mendefinisikan seseorang yang memiliki kematangan emosi adalah orang yang dapat mengontrol kehidupan emosi dirinya dengan baik. Kaplan dan Baron (dalam Mahmoudi, 2012) menguraikan karakteristik dari seseorang yang dewasa secara emosional, yaitu ia memiliki kapasitas untuk menunda pemenuhan kebutuhan, memiliki keyakinan dalam perencanaan jangka panjang, dan mampu menunda atau merevisi harapan terkait tuntutan situasi. Seorang remaja yang dewasa secara emosional memiliki kapasitas untuk membuat penyesuaian yang efektif dengan dirinya sendiri, anggota keluarganya, teman-teman sekolahnya dan lingkungan sosial sekitarnya.

Kematangan emosi membuat remaja 
mampu mengembangkan hubungan yang sehat dengan lingkungan sosialnya. Dalam hubungan yang sehat ini, remaja akan dapat mengelolah emosinya, berusaha menyesuaikan diri dengan suasana orang lain, dan mencari keharmonisan dalam menjalin hubungan dengan orang lain (Mahmoudi, 2012). Jika kematangan emosi belum tercapai, maka remaja kemungkinan besar tidak mampu mengendalikan emosinya secara efektif yang pada gilirannnya akan menghambat hubungan sosialnya dengan orang lain.

Menurut Murray (dalam Astuti, 2009) aspek-aspek yang terkandung dalam kematangan emosi remaja antara lain: (1) pemberian dan penerimaan cinta, yaitu mampu mengekspresikan cintanya sebagaimana remaja dapat menerima cinta dan kasih sayang dari orang-orang yang mencintainya; (2) pengendalian emosi, yaitu individu yang matang secara emosi dapat menggunakan amarahnya sebagai sumber energi untuk meningkatkan usahanya dalam mencari solusi; (3) toleransi terhadap frustrasi, yaitu ketika hal yang diinginkan tidak berjalan sesuai dengan keinginan, individu yang matang secara emosi mempertimbangkan untuk menggunakan cara atau pendekatan lain; dan (4) kemampuan mengatasi ketegangan, yaitu pemahaman yang baik akan kehidupan menjadikan individu yang matang secara emosi; yakin akan kemampuannya untuk memperoleh apa yang diinginkannya sehingga remaja dapat mengatasi ketegangan.

Remaja yang diasuh dalam sebuah keluarga yang lengkap dimana kedua orang tuanya menjalankan peran yang efektif besar kemungkinan akan lebih mampu mencapai kematangan emosi daripada remaja yang berasal dari keluarga tidak lengkap. Beberapa penelitian menunjukkan pengaruh kondisi keluarga tidak utuh terhadap perkembangan anak. Penelitian Hetherington (Dagun, 2002) menyimpulkan bahwa peristiwa perceraian dapat menimbulkan ketidakstabilan emosi, mengalami rasa cemas, tertekan dan sering marah-marah pada anak. Peristiwa perceraian juga menimbulkan berbagai akibat terhadap orang tua dan anak, tercipta perasaan yang tidak menentu. Dagun (2002) menambahkan bahwa peran ayah juga sangat besar dalam perkembangan anak. Ayah dapat mengatur serta mengarahkan aktivitas anak seperti menyadarkan anak bagaimana cara menghadapi lingkungan dan situasi di luar rumah. Hal ini merupakan salah satu cara untuk memperkenalkan anak dalam menghadapi perubahan sosial yang membantu perkembangan emosinya. Sehingga kelompok anak yang kurang mendapat perhatian ayahnya cenderung memiliki kemampuan akademis rendah, aktivitas sosial terhambat, dan interaksi sosialnya terbatas (Dagun, 2002). Keberadaan figur ibu juga tak kalah penting dalam menentukan perkembangan emosi anak. Freud (Dagun, 2002) menyatakan bahwa hubungan anak dengan ibunya sangat berpengaruh dalam pembentukan pribadi dan sikap-sikap sosial anak di masa mendatang karena ibu adalah tokoh utama dalam proses awal sosialisasi anak.

Keberadaan figur ayah dan ibu yang berfungsi secara tepat dalam sebuah keluarga karena itu menjadi penentu awal perkembangan emosi anak. Ketiadaan salah satu figur tersebut membuat fungsi keluarga menjadi tidak lengkap atau sempurna, dan dapat berdampak pada terhambatnya anak mencapai kematangan emosi. Ahmadi (2007) mengartikan keluarga lengkap sebagai keluarga yang terdiri dari ayah, ibu dan anak di mana kedua orang tua memiliki suatu kebulatan sebagai orang tua terhadap anaknya dan memiliki perhatian yang penuh atas tugastugasnya sebagai orang tua. Selanjutnya Gunarsa \& Gunarsa (2004) menggambarkan keluarga yang normal atau lengkap memiliki 
ciri-ciri sebagai berikut: a) Ayah dan ibu masih hidup; b) Ayah dan ibu mampu memenuhi kebutuhan rumah tangga serta kebutuhan pendidikan anak-anaknya; c) Ayah dan ibu selalu menempatkan diri untuk mengetahui perkembangan pendidikan anaknya dan ibu yang mampu mendidik anak-anaknya di rumah dengan sebaik mungkin; d) Ayah dan ibu mampu memenuhi kebutuhan psikologis anak-anaknya.

Sebaliknya, Gerungan (2010) mengistilahkan keadaan keluarga yang sudah tidak lengkap atau tidak utuh dengan istilah perpecahan keluarga. Perpecahan keluarga adalah suatu keluarga dimana struktur keluarganya sudah tidak lengkap lagi. Ketidaklengkapan keluarga bisa meliputi: a) Ayah/ibu/keduanya tidak ada (meninggal dunia); b) Orang tua yang hidup bercerai. Sebuah keluarga dimana didalamnya hanya terdapat satu orang tua yang tinggal sendiri yaitu ayah saja atau ibu saja sering disebut dengan keluarga single parent. Orang tua tunggal (single parent) dapat terjadi karena: a) Perceraian; b) Salah satu meninggalkan keluarga atau rumah; c) Salah satu meninggal dunia (Surya, 2003).

Balson (dalam Yuniardi \& Djudiyah, 2011) mengatakan bahwa pada keluarga single parent, orang tua berperan ganda dalam menjalankan kewajibannya sebagai orang tua sehingga dapat menghambat hubungan antara anak dan orang tua. Orang tua maupun anak biasanya kurang mampu beradaptasi dan menerima keadaan tersebut. Keadaan seperti ini dapat menimbulkan konflik antar anggota keluarga, sehingga memunculkan masalah baik dari pihak orang tua maupun anak terutama ketika berusia remaja. Kondisi tersebut dapat mempengaruhi perkembangan remaja menuju tahap kematangan emosi.

Remaja yang hidup dalam sebuah keluarga dengan orang tua tunggal kemungkingan besar akan mengalami pola pengasuhan yang tidak lengkap yang akan berdampak pada kematangan emosinya seperti kecenderungan menjadi pemarah, suka melamun bahkan suka menyendiri (Munandar, 2000). Namun tidak semua remaja yang berada dalam keluarga seperti ini akan mengalami dampak psikologis yang sama. Penelitian Retnowati (2005) mengemukakan bahwa pola komunikasi yang diterapkan orang tua tunggal (ibu) mempengaruhi tinggi rendah kemandirian anak. Pola komunikasi interaksi dan transaksi membuat anak dari keluarga tunggal menjadi lebih mandiri, sedangkan pola komunikasi linear membuat kemandirian anak rendah. Dengan demikian dapat diasumsikan bahwa keluarga dengan orng tua tunggal belum dapat dipastikan terkait secara langsung dengan rendahnya kemandirian. Hurlock (1996) mengemukkan bahwa karakteristik yang dimiliki oleh seorang yang mandiri adalah juga karakteristik yang dimiliki oleh orang yang memiliki kematangan emosi, yaitu mampu bertindak berdasarkan pertimbangan dan keinginan pribadi dan bukan ditentukan oleh orang di luar dirinya. Karaktristik ini menunjukkan bahwa orang tersebut adalah individu yang matang secara emosi karena dapat mengendalikan dirinya.

Penelitian ini bertujuan untuk membandingkan kematangan emosi antara remaja yang diasuh dalam keluarga yang lengkap dan remaja yang berasal dari keluarga single parent. Penelitian ini mengemukakan hipotesis bahwa ada perbedaan kematangan emosi pada remaja remaja dari keluarga single parent atu tidak lengkap dengan remaja dari keluarga yang lengkap.

\section{METODE}

Pendekatan pada penelitian ini menggunakan pendekatan kuantitatif komparatif. Metode penelitian kuantitatif komparatif adalah penelitian yang bersifat membandingkan keberadaan satu variabel 
pada sampel yang berbeda, atau dalam waktu yang berbeda (Sugiyono, 2012).

\section{Sampel}

Penelitian ini menggunakan dua populasi, yaitu populasi remaja dari keluarga lengkap dan populasi remaja dari keluarga single parent di kelurahan Kedung Pandan kecamatan Jabon kabupaten Sidoarjo, Jawa Timur. Penggunaan dua populasi pada penelitian ini dilakukan karena tujuan penelitian ini adalah untuk mencari perbedaan kematangan emosi antara remaja dari keluarga lengkap dengan remaja dari keluarga single parent. Sampel dalam penelitian ini berjumlah 121 remaja yang berusia 16-20 tahun terdiri dari 86 remaja berasal dari keluarga lengkap dan 35 orang berasal dari keluarga single parent. Sampel penelitian ini diperoleh dengan teknik simple random sampling, yaitu pengambilan anggota sampel dari populasi yang dilakukan secara acak tanpa memperhatikan strata dalam populasi karena populasi dianggap homogen (Sugiyono, 2012). Teknik sampling ini dilakukan berdasarkan tabel penentuan jumlah sampel dalam populasi yang dikembangkan oleh Isaac dan Michael (dalam Sugiyono, 2012).

\section{Teknik pengumpulan data}

Pengumpulan data dilakukan dengan menggunakan skala kematangan emosi berdasarkan modifikasi dari indikator aspekaspek kematangan emosi dari setiap komponen kematangan emosi yang dikembangkan oleh Murray (dalam Astuti, 2009), yaitu: 1) pemberian dan penerimaan cinta, yaitu individu mampu menerima keadaan dirinya dan orang lain disekitarnya termasuk pada orang-orang yang mencintainya; (2) pengendalian emosi, yaitu individu yang matang secara emosi dapat menggunakan amarahnya sebagai sumber energi untuk meningkatkan usahanya dalam mencari solusi; (3) toleransi terhadap frustrasi, yaitu ketika hal yang diinginkan tidak berjalan sesuai dengan keinginan, individu yang matang secara emosi mempertimbangkan untuk menggunakan cara atau pendekatan lain; dan (4) kemampuan mengatasi ketegangan, yaitu pemahaman yang baik akan kehidupan menjadikan individu yang matang secara emosi; yakin akan kemampuannya untuk memperoleh apa yang diinginkannya sehingga remaja dapat mengatasi ketegangan.

Skala tersebut berbentuk skala Likert, dimana responden memberikan rating pada setiap pernyataan yang memiliki rentang pilihan jawaban 1-5. Skor diperoleh dari penjumlahan rating tersebut. Sedangkan untuk penentuan struktur keluarga lengkap atau single parent diperoleh dari data dokumentasi kelurahan setempat, yaitu rekapitulasi Kartu Keluarga (KK). Uji validitas pada 64 item pernyataan skala dilakukan dengan melakukan tabulasi skor untuk mengetahui validitas instrumen dengan cara koefisien korelasi product moment dari Pearson. Sedangkan, Uji realibilitas dilakukan menggunakan Cronbach Alpha dengan bantuan SPSS for Windows versi 17.0. Hasil uji validitas skala kematangan emosi dengan $r_{\text {hitung }} \geqslant 0,30$ mengalami 3 kali putaran menunjukkan bahwa dari 64 item yang telah disediakan, 46 item dinyatakan valid karena memiliki koefisien $\geq 0,30$ dan 18 item gugur karena koefisien $\leq 0,30$.

\section{Teknik Analisis Data}

Teknik analisis data yang digunakan pada penelitian ini disesuaikan dengan tujuan penelitian yaitu menguji hipotesis perbedaan kematangan emosi remaja ditinjau dari struktur keluarga yaitu dengan teknik uji-t sampel independen. 


\section{HASIL DAN PEMBAHASAN}

Hasil penelitian ini menunjukkan bahwa kematangan emosi remaja dari keluarga lengkap dan remaja dari keluarga orang tua tunggal (single parent) memiliki rata-rata skor kematangan emosi yang berbeda. Berikut paparan hasil rata-rata skor kematangan emosi pada kedua kelompok sampel:

Tabel 1. Deskripsi data skor kematangan emosi

\begin{tabular}{lrrrrrr}
\hline & N & Min. Max. Variance & Mean & $\begin{array}{c}\text { Std. } \\
\text { Deviation }\end{array}$ \\
\hline $\begin{array}{l}\text { Single } \\
\text { Parent }\end{array}$ & 35 & 129 & 179 & 112,445 & 148,71 & 10.604 \\
$\begin{array}{l}\text { Keluarga } \\
\text { Lengkap }\end{array}$ & 86 & 116 & 167 & 89,734 & 143,77 & 9,473 \\
\hline
\end{tabular}

Tabel 1. menunjukkan bahwa rata-rata skor kematangan emosi pada remaja dari keluarga single parent ialah sebesar 148,71 dengan nilai tertinggi 179 dan nilai terendah 129 , variasi 112.445 serta standar deviasinya sebesar 10,604. Sedangkan untuk remaja dari keluarga lengkap, rata-ratanya sebesar 143,77 dengan nilai tertinggi 167 dan nilai terendah 116 , variasi datanya 89,734 serta standar deviasinya sebesar 9,473. Berdasarkan nilai mean maka dapat diketahui tingkat kematangan emosi yang diperoleh yaitu terdapat 44 remaja dari keluarga lengkap memperoleh skor di atas nilai rata-rata, dan 42 sampel berada dibawah nilai rata-rata. Sedangkan pada remaja dari keluarga single parent terdapat 17 sampel berada di atas nilai rata-rata dan 18 sampel memperoleh skor dibawah rata-rata.

Uji normalitas pada penelitian ini menggunakan teknik one sample Kolmogorov-Smirnov test yang dikatakan normal jika $\mathrm{p} \geq 0,05$. Uji normalitas dalam penelitian ini dengan bantuan program SPSS Versi 17.0 for windows. Adapun hasil uji normalitas adalah sebagai berikut
Tabel 2. Hasil Uji Normalitas Data (Kolmogorov-Smirnov Test)

\begin{tabular}{ccc}
\hline & $\begin{array}{c}\text { Keluarga } \\
\text { Lengkap }\end{array}$ & $\begin{array}{c}\text { Single } \\
\text { Parent }\end{array}$ \\
\hline $\mathrm{N}$ & 86 & 35 \\
Kolmogorov-Smirnov Z & 0,652 & 0,464 \\
Asymp. Sig. (2 tailed) & 0,789 & 0,982 \\
\hline
\end{tabular}

Berdasarkan hasil uji normalitas tersebut, diketahui bahwa nilai Asymp.sig (2tailed) pada subyek dari keluarga lengkap sebesar 0,789, dan pada subyek remaja dari keluarga single parent sebesar 0,982. Karena nilai signifikansi lebih dari 0,05 maka variabel kematangan emosi pada kedua kelompok sampel dinyatakan berdistribusi normal.

Uji homogenitas pada uji perbedaan dimaksudkan untuk menguji bahwa setiap kelompok yang akan dibandingkan memiliki variansi yang sama. Pengujian dilakukan dengan test of homogenity of variance dari SPSS Versi 17.0 for windows pada ketetapan taraf signifikansi $\alpha \geq 0,05$. Analisis data dengan bantuan SPSS for windows versi 17.0 mendapatkan hasil sebagai berikut:

Tabel 3. Hasil Uji-T Independent Samples

\begin{tabular}{cccc}
\hline & \multicolumn{3}{c}{ Kematangan Emosi } \\
\cline { 2 - 4 } & \multicolumn{2}{c}{$\begin{array}{c}\text { Equal } \\
\text { variances } \\
\text { assumed }\end{array}$} & $\begin{array}{c}\text { Equal } \\
\text { variances } \\
\text { not assumed }\end{array}$ \\
\hline $\begin{array}{c}\text { Levene's Test for } \\
\text { Equality of } \\
\text { Variances }\end{array}$ & F & 0,460 & \\
$\begin{array}{c}\text { T-test for Equality } \\
\text { of Means }\end{array}$ & $\begin{array}{c}\text { Sig. (2- } \\
\text { tailed) }\end{array}$ & 0,013 & 0,020 \\
\hline
\end{tabular}

Berdasarkan tabel di atas diketahui bahwa nilai signifikansi dari uji Levene's adalah 0,499 yang berarti lebih besar dari 0,05 . Dengan demikian dapat dikatakan bahwa kedua kelompok sampel, remaja dari keluarga lengkap dan keluarga orang tua tunggal (single parent), memiliki variansi yang sama.

Tahap selanjutnya ialah melakukan uji- 
$\mathrm{t}$ sampel independen (independent sample test). Dari tabel dapat diketahui bahwa uji-T menghasilkan nilai signifikansi sebesar 0,013 , yang berarti lebih rendah dari 0,05. Dengan demikian, hipotesis dari penelitian ini, yaitu ada perbedaan kematangan emosi remaja ditinjau dari struktur keluarga, dapat diterima. Sesuai dengan hasil analisis data, perbedaan kematangan emosi yang muncul adalah remaja yang berasal dari keluarga lengkap memiliki kematangan emosi lebih rendah dengan rata-rata skor sebesar 143,77 dibanding remaja dari keluarga single parent dengan rata-rata skor 148,71.

Hasil penelitian ini dapat dikatakan mendukung penelitian terdahulu yang menyatakan adanya perbedaan kematangan emosi pada individu dari keluarga lengkap dan dari keluarga orang tua tunggal. Penelitian Herawati (2005) menghasilkan kesimpulan bahwa ada perbedaan kematangan emosi antara mahasiswa yang berasal dari keluarga utuh dengan yang berasal dari keluarga tidak utuh, yaitu hanya ibu (karena perceraian maupun kematian). Namun berbeda dengan hasil penelitian ini, penelitian Herawati (2005) menyimpulkan bahwa bahwa skor kematangan emosi pada mahasiswa dari keluarga utuh lebih tinggi daripada skor ratarata kematangan emosi pada mahasiswa dari keluarga tidak utuh.

Hasil berbeda ditunjukkan oleh penelitian Yuliawati \& Setiawan (2007) yang menguji perbedaan kecerdasan emosi pada remaja dari keluarga lengkap dan dari keluarga tanpa ayah karena perceraian dan kematian. Penelitian tersebut menyimpulkan tidak ada perbedaan dalam kecerdasan emosi pada kedua kelompok sampel tersebut. Goleman (1997) mendefinisikan kecerdasan emosi sebagai kemampuan dalam mengendalikan emosi, memotivasi diri, menunda kepuasan, mengatur keadaan jiwa, dan ketahanan dalam menghadapi kegagalan. Sementara Manoharan \& Doss (2007) mengemukakan bahwa kematangan emosi dicirikan oleh kemampuan dalam menunjukkan emosi dalam derajat yang tepat dan dapat diterima lingkungan sekitarnya serta kemampuan dalam pengendalian diri yang wajar dan mendahulukan pikiran rasional. Berdasarkan pada kedua definisi tersebut, meskipun tidak dapat disebut sama, "kecerdasan emosi" dan "kematangan emosi" memiliki keterkaitan yang erat karena saling berbagi beberapa karakteristik yang sama.

Tidak adanya konsistensi dari beberapa penelitian sebelumnya terkait peran struktur keluarga dalam menentukan kematangan emosi, kecerdasan emosi, maupun kemandirian remaja menunjukkan adanya factor lain yang mempengaruhi. Penelitian Yuliawati dkk. (2007) menunjukkan alasan bahwa masa usia anak pada saat ketiadaan ayahnya karena meninggal atau perceraian menentukan perbedaan kecerdasan emosi anak. Remaja yang mengalami ketiadaan ayah saat usia mereka 0-4 tahun sebagian besar merasa tidak mengalami perubahan apaapa. Tidak ada satupun diantara mereka merasa kehilangan ayah karena pada masa itu, justru peran ibu yang lebih mendominasi. Sementara itu sebagian besar remaja yang mengalami ketiadaan ayah pada usia 5-10 tahun menjadi lebih tegar, mandiri, religius, dan lebih patuh pada ibu. Sebagian besar remaja yang mengalami yang mengalami ketiadaan ayah pada usia 11 sampai 15 tahun (usia remaja awal) justru mengalami masalah emosi seperti merasa kesepian, kesedihan, merasa kurang diperhatikan.

Terkait dengan alasan ketiadaan figur ayah, Santrock (2003) menjelaskan bahwa dampak negatif perceraian lebih tinggi daripada dampak kematian terhadap kondisi emosi remaja. Perceraian adalah masalah berat bagi kondisi remaja karena berkaitan dengan konflik yang berpengaruh lebih besar bagi remaja daripada perubahan struktur keluarga itu sendiri. Jadi remaja yang berasal 
dari keluarga bercerai jauh lebih mungkin mengalami masalah emosi daripada remaja yang orang tuanya meninggal, karena konflik yang muncul pada situasi sebelum dan sesudah perceraian. Remaja yang orang tuanya meninggal memang mengalami masalah emosi seperti respon berdukacita. Namun maslah ini lebih mudah terselesaikan.

Selain itu, Yuliawati dkk. (2007) juga menunjukkan bahwa factor kedekatan anak dengan figur ayah maupun ibu lebih menentukan kondisi psikologis anak daripada struktur keluarga. Hamalik (2004) menjelaskan bahwa karakteristik lingkungan keluarga yang ditandai oleh adanya perhatian yang cukup, rasa kasih sayang, suasana yang penuh persaudaraan dan persahabatan, penghormatan terhadap diri personal, keterbukaan dan sikap penerimaan, dan suasana humoris dapat mempengaruhi cara pengelolaan emosional tiap individu. Dapat dikatakan bahwa untuk mendukung pencapaian kematangan emosi remaja, selain keberadaan orang tua, remaja juga membutuhkan kedekatan secara emosional dengan mereka.

Steinberg (dalam Yuliawati dan Setiawan, 2007) juga menjelaskan bahwa berbagai penelitian mengenai keluarga single parent justru lebih mengarah pada kesimpulan bahwa kualitas relasi remaja yang bermakna dengan orang yang dikasihinya, termasuk orang tua, lebih berdampak penting terhadap kondisi psikologisnya daripada sekedar keberadaan orang tua dalam keluarga. Penjelasan Steinberg tersebut memperkuat argumentasi bahwa struktur keluarga yang berbeda tidak serta merta menyebabkan kematangan emosi yang berbeda pada remaja. Kematangan emosi remaja banyak ditentukan oleh bagaimana remaja mempersepsi kualitas relasi dengan orang tuanya.

\section{SIMPULAN}

Berdasarkan hasil penelitian dan pembahasan di atas, maka dapat ditarik kesimpulan bahwa ada perbedaan kematangan emosi remaja ditinjau dari struktur keluarga. Artinya, struktur keluarga lengkap dan keluarga single parent menghasilkan dampak berbeda terhadap kematangan emosi remaja. Hasil penelitian ini menunjukkan bahwa skor kematangan emosi justru lebih tinggi pada remaja dari keluarga orang tua tunggal (ibu) dibanding pada remaja dari keluarga lengkap. Hasil penelitian ini semakin menunjukkan ketidakkonsistenan beberapa kesimpulan penelitian sebelumnya yang menguji dampak maupun kaitan antara struktur keluarga dengan kematangan emosi, kecerdasan emosi, maupun kemandirian remaja. Sebagian penelitian yang telah dilakukan menyimpulkan ada hubungan antara struktur keluarga dengan kematangan emosi dengan skor lebih tinggi dimiliki remaja dari keluarga lengkap. Sebagian penelitian lain menunjukkan tidak ada hubungan antara struktur keluarga dengan kecerdasan emosi. Ketidakkonsistenan hasil penelitian ini dengan beberapa penelitian sebelumnya menunjukkan bahwa terdapat faktor lain selain struktur keluarga yang menentukan kematangan emosi, kecerdasan emosi, maupun kemandirian pada remaja yang berasal dari keluarga utuh maupun tidak lengkap. Tiga faktor utama yang dapat diidentifikasi sebagai penentu adalah alasan ketiadaan figur salah satu orang tua, masa usia anak ketika salah satu orang tuanya tiada, dan kualitas hubungan yang bermakna antara anak dan orang tuanya. 


\section{DAFTAR PUSTAKA}

Ahmadi, A. (2007). Psikologi Sosial. Jakarta: Rineka Cipta.

Astuti, B. (2009). Efektivitas Bimbingan dan Konseling Perkembangan untuk Meningkatkan Kematangan Emosi Remaja. Makalah Disampaikan dalam Kegiatan Jurnal Club di Ruang Sidang I Fakultas Ilmu Pendidikan Universitas Negeri Yogyakarta tanggal 9 November 2011. Diakses dari http://staff.uny.ac.id, tanggal 10 Oktober 2012.

Berns, R. (2004). Child Family School Community. New York: Prentice Hall

Chaplin, J. P. (2006). Kamus lengkap psikologi. (Terjemahan). Jakarta: RajaGrafindo Persada.

Dagun, S. M. (2002). Psikologi Keluarga: Peranan Ayah dalam Keluarga. Jakarta : Rineka Cipta

Goleman, D. (1998). Emotional Intelligence (Terjemahan). Jakarta: Gramedia Pustaka Utama.

Gunarsa, S. D. \& Gunarsa, Y. S. D. (2004). Psikologi Praktis: Anak, Remaja dan Keluarga. Jakarta: BPK Gunung Mulia

Hamalik, O. (2004). Psikologi Belajar dan Mengajar. Bandung : Sinar Baru Algensindo.

Herawati, N. (2005). Kematangan Emosi Ditinjau Dari Keutuhan Keluarga. Skripsi: Fakultas Psikologi, Universitas Muhammadiyah $\mathrm{M} \mathrm{a} 1 \mathrm{a} \mathrm{ng}$. D i a k s e s d a r i http://skripsi.umm.ac.id/gdl.php?mod=bro wse\&op=read\&id=jiptummpp-gdl-s 1 $2005-n$ e t t y h e r a w 4859\&q=netty\%20herawati, pada 14 Desember 2012.

Hurlock, E. B. (1996). Psikologi Perkembangan: Suatu Pendekatan Sepanjang Rentang Kehidupan (Terjemahan). Jakarta: Erlangga.

Mahmoudi, A. (2012). Emotional Maturity and Adjustment Level of College Students.
Education Research Journal, 2 (1), 18 -19. Diakses dari http://www.resjournals.com pada 05 Oktober 2012.

Manoharan, R. J. L., \& Doss, I.C. (2007). Emotional Maturity of Post Graduate Student in Pondicherry Region. Experiments in Education, 35 (8), 161-163.

Monks, F.J., Konoers, A. M. P., \& Haditono, S. R. (2004). Psikologi perkembangan: Pengantar dalam berbagai bagiannya (revisi ke-III). Yogyakarta: Gadjah Mada University Press.

Munandar, U. (2000). Peran Single Parent dalam Menghadapi Kenakalan Anak. Anima: Indonesian Psychological Journal, 15 (4), 390-394.

Pastey, G. S. \& Aminbhavi, V. A. (2006). Impact of Emotional Maturity on Stress and Self Cofidence of Adolescents. Journal of the Indian Academy of Applied Psychology, 32 (1), 66-70. [online], (http:// www.academicjournals.org, diakses tanggal 13 Oktober 2012).

Retnowati, Y.(2007). Pola Komunikasi Orang Tua Tunggal Dalam Membentuk Kemandirian Anak. Tesis: Sekolah Pascasarjana Institut Pertanian Bogor. Diakses dari http://repository.ipb.ac.id/handle/1234567 89/10628 pada 13 Januari 2013.

Santrock, J. W. (2003). Adolescence: Perkembangan masa remaja. Edisi Keenam.(Terjemahan). Jakarta: Erlangga

Singh, D., Kaur, S. \& Dureja, G. (2012). Emotional maturity differentials among university students. Journal of Physical Education and Sports Management, 3 (3), $41-45$ [ [ o n $1 \mathrm{in} \mathrm{e}]$, (http://www.acadjourn.org/jpesm, diakses 13 Oktober 2012).

Sugiyono. (2012). Metode Penelitian Pendidikan: Pendekatan Kuantitatif, Kualitatif dan R \& D. Bandung: Alfabeta.

Surya, M. (2003). Bina keluarga. Semarang: 
Aneka Ilmu.

Yuliawati, L., Setiawan, J., \& Mulya T., (2007). Perubahan Pada Remaja Tanpa Ayah. Arkhe: Jurnal Ilmiah Psikologi, 12 (1), 919.

Yuliawati, L., \& Setiawan, J. L. (2007). Perbedaan kecerdasan emosional Remaja Ditinjau dari Keberadaan Ayah. Jurnal
Psikologi, 20 (2), 1-14.

Yuniardi, M. S. \& Djudiyah. (2011). Model Pengembangan Konsep diri Melalui Support Group Therapy: Upaya Meminimalkan Trauma Psikis Remaja dari Keluarga dari Keluarga Single Parent. Jurnal Psikologi Proyeksi,6 (1), 16-26. 